\title{
Influence of seedbed microsite characteristics on grass seed- ling emergence
}

\author{
VON K. WINKEL, BRUCE A. ROUNDY, AND JERRY R. COX
}

\begin{abstract}
Successful germination and establishment of grass seedlings from surface-sown seeds requires a microsite which provides adequate soil water and temperature conditions, among other speciesspecific requirements. The microsite where these requirements are met has been termed a "safesite". Safesites may occur naturally as cracks and depressions in the soil surface, gravel, and plant litter, or be prepared by seedbed equipment and livestock trampling. $A$ greenhouse study was conducted to determine the influence of seedbed microsite characteristics and soil water treatments on seediling emergence of 'Vaughn' sideoats grama (Bouteloua curtipendula (Michx.) Torr.), 'A-130' blue panic (Panicum antidotale Retz.), and 'Cochise' Atherstone lovegrass (Eragrostis lehmanniana Nees $\times E$. tricophera Coss and Dur.). Although there were several interactions, in general, emergence of all 3 species was highest from gravel, followed by litter, cracks, and finally the bare soil surface. Bare surface sites decreased in water content more quickly than the other sites. Cochise lovegrass had high emergence in gravel under all water treatments. Small-seeded species such as Cochise lovegrass broadcast on coarse-textured surface soils may establish with minimal seedbed preparation, provided summer precipitation is adequate.
\end{abstract}

Key Words: safesite, sideoats grama, blue panic, Cochise lovegrass, broadcast seeding, revegetation, soil water content

Perennial grass densities have decreased on many rangelands due to lack of grazing management, drought, (Cox et al. 1982), and encroachment of woody shrubs (Humphrey 1958, Cox et al. 1983). Loss of herbaceous cover could result in increased soil erosion, formation of soil crusts, and loss of favorable microsites necessary for germination and establishment of grass seedlings on some sites.

Natural revegetation of perennial grasses is slow in many areas (Hyder et al. 1971, Stoddart et al. 1975, Roundy and Jordan 1988), therefore seeding adapted species is often desirable. However, because of steep or rocky terrain, conventional methods of tilling and seeding are often impractical. On these sites the only alternative is broadcast seeding (Vallentine 1989). However, broadcast seeding is often unsuccessful on many sites (Cook 1958, Bleak and Hull 1958, McWilliam et al. 1970, Campbell and Swain 1973a, Stoddart et al. 1975).

Depending upon the species, most germination requirements are more easily met within the seedbed rather than upon it. Surfacesown seeds are exposed to many hazards including predation (Nelson et al. 1970, and Campbell and Swain 1973a), seed and seedling desiccation (Evans and Young 1972a and Campbell and Swain 1973a), and lack of radical entry (Dowling et al. 1971, Campbell and Swain 1973a, Campbell and Swain 1973b and Sheldon 1974).

Surface-sown seeds fall into a variety of micro-environments, some of which are associated with favorable water and temperature conditions for germination and establishment. Favorable microsites for seedling establishment have been described by Harper et

\footnotetext{
Authors are graduate research associate and associate professor, School of Renewable Natural Resources, University of Arizona, Tucson 85721 , and range scientist, Aridland Watershed Management Research Unit, USDA-ARS, 2000 East Allen Road, Tucson, Arizona 85719.

Research was funded by a grant from the USDA Rangeland Research program. Published as Arizona Agricultural Experiment Station Paper

Manuscript accepted 13 June 1990.
}

al. (1961) and Harper (1977) as "safesites". Natural safesites may include cracks and depressions in the soil surface, or sites associated with gravel, and plant litter.

In a classic study, Harper et al. (1965) reported increased emergence from surface-sown seeds of Plantago spp. placed in soil depressions and near various objects, including glass sheets and wood boxes. They also reported increased emergence from seeds of Bromus rigidus (Roth.) when sown in large soil aggregates, and $B$. madritensis $(L$. $)$ when sown in small soil aggregates. They explained the differential emergence in terms of the different types of contact the seeds made with the aggregates. In a similar study, also using various artificial objects, Sheldon (1974) showed that treatments imposing a high humidity over the treatment area had better emergence than those that did not.

This evidence indicates that one of the most important characteristics of a microsite that makes it a safesite is its association with high humidity and soil moisture. Harper et al. (1965) and Sheldon (1974) both worked under mesic conditions in Great Britain. On arid and semiarid rangelands where storms are less frequent and seedbeds may rapidly dry out, microsites may still be associated with increased emergence. Evans and Young (1972a) reported 100 times greater emergence of downy brome (Bromus tectorum L.) seedlings from seeds sown in 9-mm deep soil pits as compared to seeds sown on the bare soil surface in Nevada. Soil water and humidity in the pits were much more favorable for germination than the bare soil surface. In a survey of plant responses to various microsites in the Great Basin, Eckert et al. (1986) found more seedlings of Wyoming big sagebrush (Artemisia tridentata wyomingensis Beetle), perennial grasses, and annual forbs emerging from cracks and trenches than on the unprotected soil surface.

Evans and Young $(1970,1972 b)$ reported much greater emergence of downy brome, medusahead rye (Taeniatherum asperum Simonkai) Nevski), and Russian thistle (Salsola iberica L.) from seeds under litter than from seeds on the soil surface. Environmental monitoring showed that litter greatly moderated maximum and minimum temperatures, decreased the amount of light reaching the soil surface, and greatly increased relative humidity.

In the semidesert grasslands of the Southwest, $60-70 \%$ of annual precipitation falls between July and October. At certain times during this period, conditions may be mesic enough for natural seedbed microsites such as gravel, litter, and cracks and artificial microsites produced by livestock trampling and mechanical seedbed preparation to be more favorable for germination than the bare soil surface. This may help to explain why small-seeded lovegrasses broadcast on disturbed seedbeds have had emergence equal to or greater than those drilled in the Southwest (Cox et al. 1986).

Other than the few studies above, there has been little determination of the types of microsites that are adequate for germination and establishment of range plants. The objective of this study was to determine the influence of seedbed microsite characteristics on seedling emergence of 3 warm-season grasses.

\section{Methods}

A field survey was conducted at a typical semidesert grassland site on the Anvil Ranch, $65 \mathrm{~km}$ southwest of Tucson, Ariz., to determine what types of microsites may be available to seeds on 
rangelands in southern Arizona. The soil is a sandy loam (fine, mixed, thermic Ustollic Haplargid) and supports mesquite (Prosopis juliflora Swartz.), snakeweed (Gutierrezia sarothrae Pursh), and remnant native grasses such as Arizona cottontop (Digitaria californica (Benth) Henr.) and purple three awn (Aristida purpurea Nutt.).

Three obvious microsites were gravel, cracks in the soil crust, and litter. To determine the percent composition of the gravel microsites, $2 \mathrm{~m}^{2}$ of the top $1 \mathrm{~cm}$ of the soil surface was collected, sieved, and each fraction weighed. Of the sample, $45 \%$ was gravel, $39 \%$ was sand, and $15 \%$ was silt and clay. Of the gravel fraction, $66 \%$ was between 2 and $5 \mathrm{~mm}, 21 \%$ was between 5 and $10 \mathrm{~mm}$, and $13 \%$ was greater than $10 \mathrm{~mm}$.

Percent litter cover was determined with a point frame. Of 1,600 points, 281 hit litter; thus litter cover equaled $17.6 \%$. Litter was composed of dead stems of half shrubs and grasses and located mainly beneath living plants and in litter dams. Cracks were common but most were less than $0.5 \mathrm{~mm}$ in width.

All 3 microsites described above plus a control consisting of bare uncracked soil were selected for use in the study, with the following modifications. The gravel treatment was a mixture of both the 2-5 and the 5-10 $\mathrm{mm}$ fractions and each was present in the same relative proportions found in the field. Due to the lack of an uncontaminated litter source and lack of homogeneity of litter at the survey site, fine wood excelsior was used. Crack size was increased to $2-5 \mathrm{~mm}$ wide by $15-20 \mathrm{~mm}$ deep.

The study was conducted in a temperature-controlled greenhouse with average minimum and maximum temperatures of 17 and $46^{\circ} \mathrm{C}$, respectively. Percent relative humidity ranged from 4 to $72 \%$.

Soil from the A horizon (top $20 \mathrm{~cm}$ ) of the microsite survey area was sieved to $5 \mathrm{~mm}$ and placed in $10 \times 10 \times 10 \mathrm{~cm}$ pots. All soil in the pots was then subjected to 2 wet-dry cycles to simulate field soil conditions. The microsites were then applied as follows. Three cracks 2-5 $\mathrm{mm}$ wide, $15-20 \mathrm{~mm}$ deep, and $80-100 \mathrm{~mm}$ long were formed in crack treatment pots with a knife in moist soil. Twentyfive $\mathrm{cm}^{3}$ of gravel from the survey site was added to the soil surface of the gravel pots. This amounted to a layer approximately $10-\mathrm{mm}$ deep. Wood excelsior was cut into $20-50-\mathrm{mm}$ lengths and placed on the litter treatment pots to a depth of $10-20 \mathrm{~mm}$. Bare surface pots were left untouched.

Twenty-five seeds each of 'Vaughn' sideoats grama (Bouteloua curtipendula (Michx.) Torr.), 'A-130' blue panic (Panicum antidotale Retz.), or 'Cochise' Atherstone lovegrass (Eragrostis lehmanniana Nees $\times$ E. tricophera Coss and Dur.) were sprinkled onto the soil surface of pots with gravel, litter, or bare microsites. Seeds were sown beneath rather than on gravel and litter. Pots with cracks were sown using a thin funnel to carefully place seeds near the bottom of cracks.

Three watering treatments were implemented, including (1) daily watering to maintain wet soil conditions, (2) watering on day 1 and day 5 (when seedlings showed signs of stress), and (3) watering on day 1 only. These conditions were selected to simulate the wide range of soil water conditions that may occur during the rainy season in southern Arizona. Watering was accomplished by subirrigation to minimize microsite disturbance.

The experimental design was a split plot with 4 blocks. Whole plots were water treatments, and microsites and species were split plots. Each block contained 72 pots: 3 species, 4 microsites, and 3 water treatments with 2 pots per species-microsite-water treatment combination.

To determine why seeds and seedlings responded as they did to the microsites, gravimetric soil water content was measured for samples from additional unseeded pots. The pots were filled with soil, conditioned with 2 wet-dry cycles, irrigated, and treated with the microsites as were the seeded pots. Eight samples per micrositewater treatment combination were collected daily.

Beginning on day $I$ and continuing daily throughout the study, approximately $10 \mathrm{~cm}^{3}$ of soil from the top $5 \mathrm{~mm}$ of mineral soil from the bare surface, gravel, and litter microsites were collected from the unseeded pots. Samples from the pots with the crack microsite were collected by removing the soil core from the pot, carefully splitting the core lengthwise down 1 crack and then scraping approximately $10-15 \mathrm{~cm}^{3}$ of soil from the bottom of the crack (between 10 and $20 \mathrm{~mm}$ from the soil surface). Gravimetric soil water content of the samples was determined by weighing before and after oven-drying (Hillel 1982). This method was selected because of the necessity of sampling the small interface between the soil and seed. Soil used in the study was analyzed for percent water content at -0.03 and $-1.50 \mathrm{MPa}$ matric potentials with a pressure plate.

Seedling emergence data were collected daily beginning on day 4. Seedling emergence criteria per microsite were as follows: (1) bare surface, seedlings $>15 \mathrm{~mm}$ and radicles penetrating the soil surface; (2) gravel and litter, seedlings above gravel or litter; and (3) cracks, seedlings even with soil surface.

Temperatures within microsites were measured with a probe type thermocouple thermometer from day 1 until day 4 . The temperature probe was placed between gravel or litter and the soil surface, within cracks, or directly on the soil surface. Air temperature was also measured $1 \mathrm{~cm}$ above the soil surface.

Seedling density data were converted to percent emergence of germinable seed. Germinability was determined in the greenhouse with 4 replications of each species using petri dish techniques. For each replication, 100 seeds were placed on Whatman No. 2 filter paper in a petri dish. Seeds were then watered and the dish was placed in its respective block. Germination counts were made every 24 hours ( + or $-1 \mathrm{hr}$ ) after initial watering. A seed was considered germinated when its radicle had emerged. Analysis of variance was performed on the arcsin square root of percentage data as suggested by Sokal and Rohlf (1981) for seedling emergence and soil water content and significant means were separated with the LSD test.

\section{Results and Discussion}

\section{Seedling Emergence}

Analysis of variance of seedling density data showed significant $(P<0.05) 2,3$, and 4-factor interactions involving days, species, water treatments, and microsites, therefore, results are based on comparisons of day-species-water treatment-microsite means.

In general, under conditions of daily watering $(>-0.03 \mathrm{MPa})$, all microsites produced significantly more seedlings $(P<0.05)$ than the bare surface (Fig. 1). Emergence of all species was highest from gravel, followed by litter, then crack microsites. Cochise lovegrass was the only species to emerge from the bare surface.

Watering on days 1 and 5 resulted in lower seedling emergence than under daily watering. Only Cochise lovegrass emerged from the bare surface. Emergence of the different species varied relative to gravel, litter, and crack microsites. Sideoats grama emergence was similar for gravel and crack microsites during the first few days, but thereafter, seedlings in cracks began to die. Seedling emergence was generally highest from gravel, less from cracks, and least from litter microsites. Blue panic seedling emergence was similar from gravel and litter microsites. Cracks produced the most blue panic seedlings, but after day 9 , seedlings began to die. Cochise lovegrass emerged best from gravel. Litter and cracks produced similar seedling emergence, but seedlings in cracks began dying after day 9 .

Premature mortality of seedlings in cracks may have been due to the method of crack preparation. The action of the knife in moist 


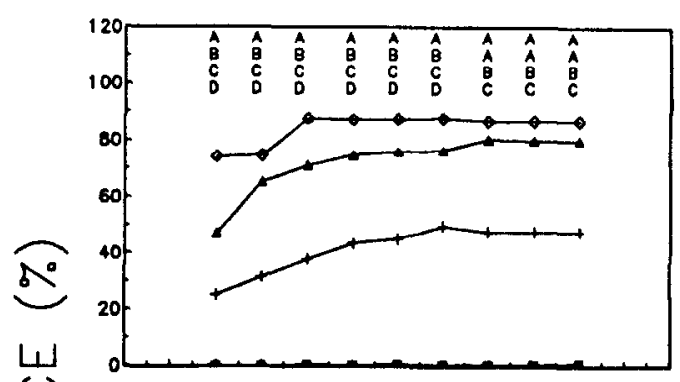

BLUE PANIC - WATER TREATMENT

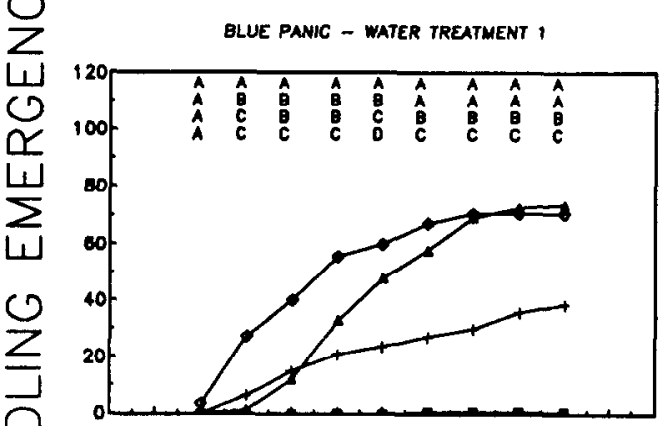

COCHISE LOVEGRASS - WATER TREATMENT I

LI

o

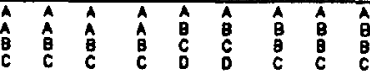

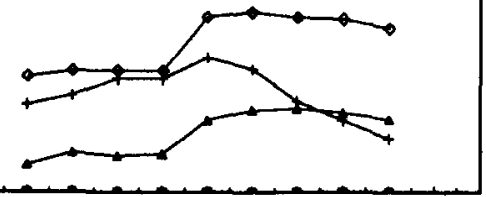

BLUE PANIC - WATER TREATMENT 2

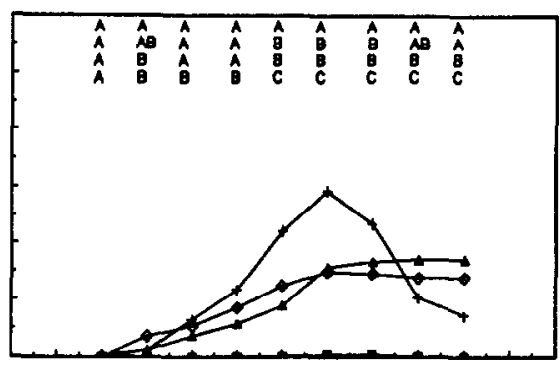

COCHISE LOVEGRASS - WATER TREATMENT 2

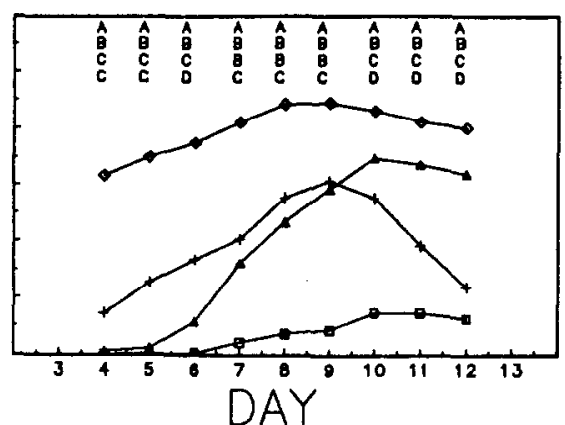

DAY
COCHISE LOVEGRUSS - WATER TREATMENT 3

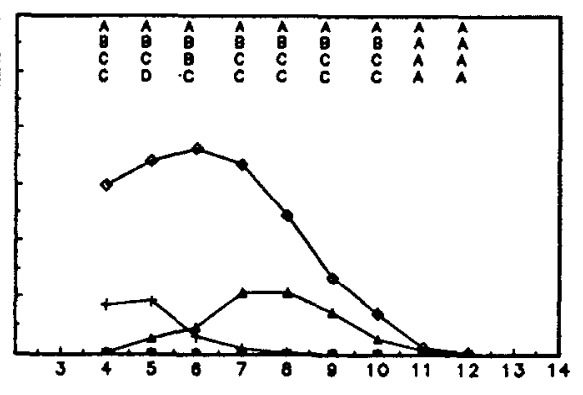

BLUE PANIC - WATER TREATMENT I
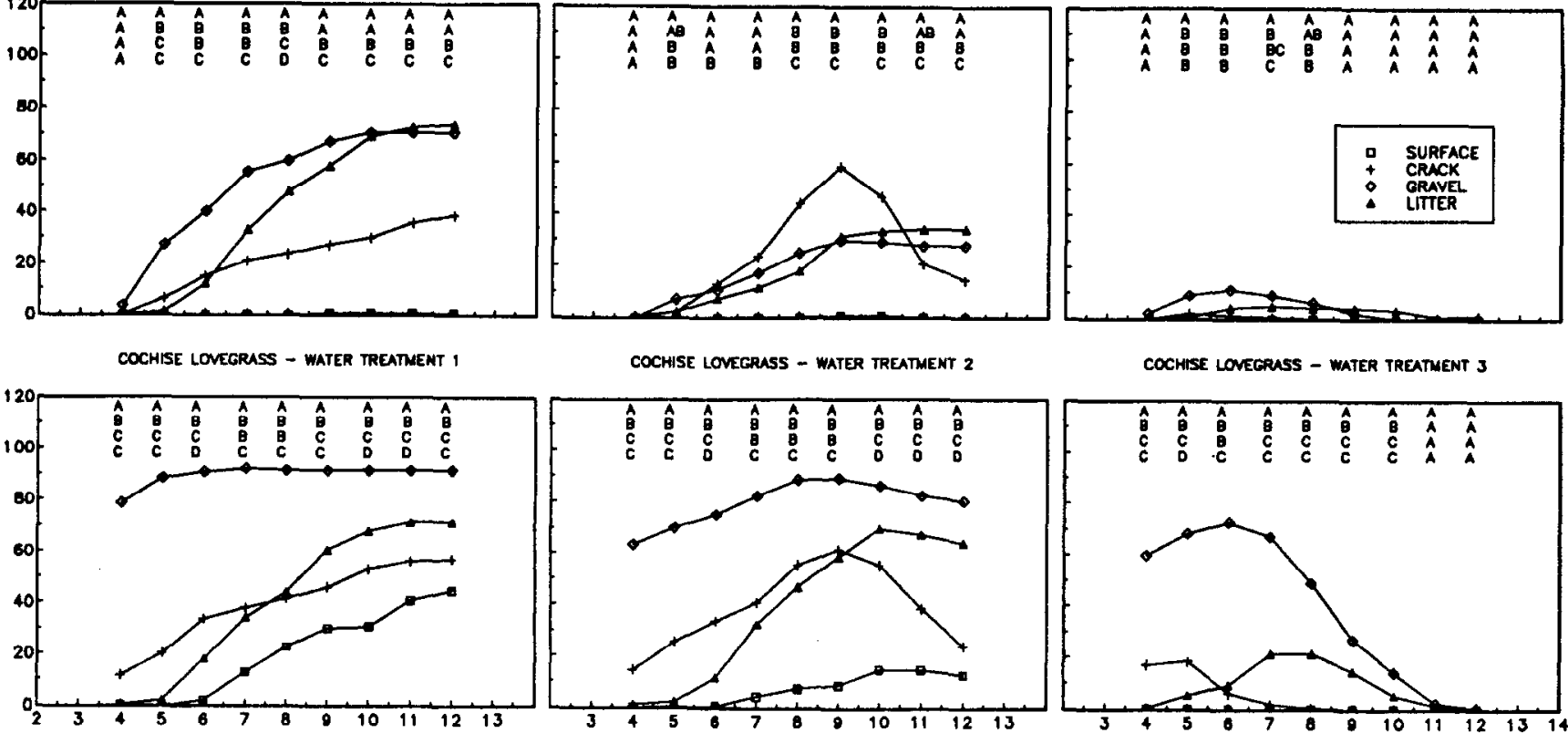

Fig. 1. Seedling emergence of sideoats grama (top row), blue panic (middle row) and Cochise lovegrass (bottom row) in various seedbed microsites in relation to 3 soil water treatments. Left column = daily watering, middle column = watering on days 1 and 5 , and right column = watering on day 1 only. Lines within a species-water treatment graph having the same letter for a given day are not significantly different $(P>0.05)$.

soil may have sealed the crack surfaces. An examination of dead seedlings from cracks showed that radicles of many seedlings had not penetrated crack walls. Natural cracks appear to have more large pores and rough edges for easier radicle penetration. In a more natural situation, seedlings may have survived longer in cracks.

Sideoats grama seedlings had the highest seedling emergence from gravel when watering occurred on day 1 only. Cracks also produced nearly as many seedlings as gravel, until seedlings began dying prematurely. All microsites produced more seedlings than the bare surface.

Results from the petri dish trial showed that blue panic requires 3-4 days of wet conditions for germination as opposed to 1 day for sideoats grama and 1-2 days for Cochise lovegrass. Total percent germination of sideoats grama, blue panic and Cochise lovegrass was 95,70 , and 82 , respectively. Watering on day 1 only did not appear to meet the germination requirements for blue panic within any of the microsites, although emergence was significantly higher $(P<0.05)$ in gravel sites than in the other sites for 3 days.

Cochise lovegrass had high seedling emergence from gravel even with watering only on day 1 . Litter and cracks had significantly more $(P<0.05)$ seedling emergence than the bare surface. Once again, there was premature mortality among seedlings in cracks.

\section{Soil Water}

The analysis of variance for soil water data showed significant 2 and 3 factor interactions involving days, water treatments, and microsites; therefore discussion of results is based on day-water treatment-microsite means. Water content of soil watered daily was greater than a corresponding matric potential of $-0.03 \mathrm{MPa}$ throughout the study for all microsites (Fig. 2).

Soil water content of soil watered on days 1 and 5 stayed above a corresponding matric potential of -1.5 MPa in the gravel and litter sites until day 9 , but only until days 4 and 5 for the bare surface and crack sites, respectively. Although soil water content increased above a corresponding matric potential of $-1.5 \mathrm{MPa}$ in cracks and on the surface after watering on day 5 , the 1 or 2 days below -1.5 MPa may have caused seed and seedling desiccation. This may help explain the significantly greater seedling emergence within the gravel and litter sites. Water content within the gravel and litter sites stayed above a corresponding matric potential of $-1.5 \mathrm{MPa}$ for 1 or 2 days longer than in the crack and bare surface sites in soil watered on day 1 only.

There was limited seedling emergence of sideoats grama and blue panic on the bare soil surface even when soil water content and corresponding soil matric potential was high. Observations showed that not only was there low emergence, but very little germination 
WATER TREATMENT 1

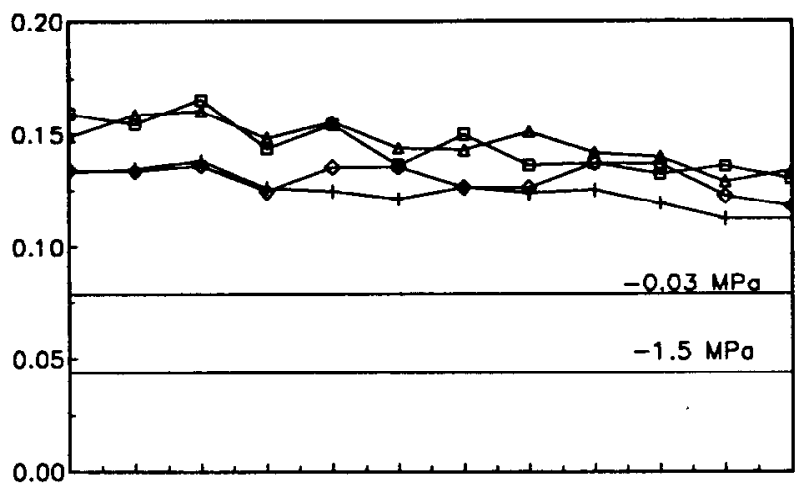

WATER TREATMENT 2

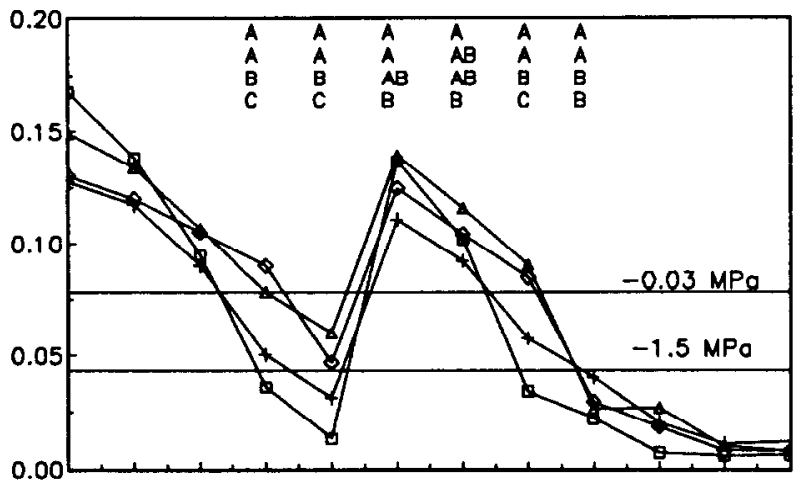

WATER TREATMENT 3

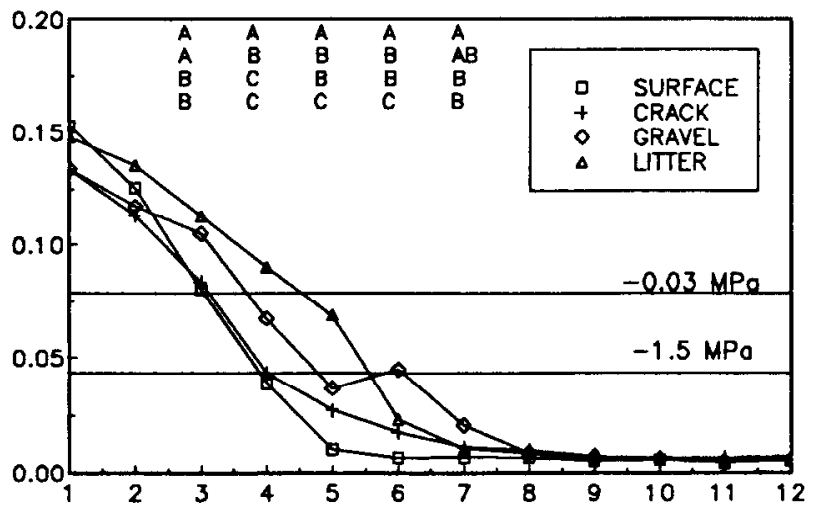

\section{DAY}

Fig. 2. Percent soil water in relation to microsites across time (days). Lines indicating soil water content at soil matric potentials of $-0.03 \mathrm{MPa}$ and $-1.50 \mathrm{MPa}$ have been added for reference. Water treatment $1=$ daily watering, water treatment 2 = watering on days 1 and 5 , and water treatment 3 = watering on day 1 only. Points within a water treatment graph having the same letter for a given day are not significantly different (P>0.05).

occurred on these sites. The greater emergence of Cochise lovegrass (small-seeded) compared with side oats grama and blue panic (larger seeded) on the bare soil may be due to greater seed-soil contact.

The ideal seedbed is one where the seed is surrounded by soil particles that are firmly packed around the seed to ensure conductivity of water from soil to seed (Collis-George and Sands 1959). Seeds on the surface have varying amounts of contact with soil. Harper (1977) stated that the degree of heterogeneity of the soil surface is dependent upon seed size. This may explain why small seeds appear to require less soil tilth or surface roughness to meet their safesite requirements (Nelson et al. 1970, Evans and Young 1972a, Cox and Martin 1984). In an associated field study (Winkel and Roundy 1991), seedling emergence of small-seeded lovegrasses in undisturbed plots with an abundance of bare soil surface was as high as in plots disturbed by cattle trampling, land imprinting, and root plowing following frequent summer rains.

The soil water results do not help explain the greater Cochise lovegrass seedling emergence from gravel, since soil water content under litter was similar to or higher than under gravel (Fig. 2). In actuality, soil surface water and relative humidity in the immediate vicinity of the seeds may have been greater under gravel than litter. The technology to measure these conditions at the scale of small seeds is not yet available (Harper et al. 1965). Another explanation may be found in the contact of seeds to gravel. Gravel appeared to lay on or next to seeds, as opposed to litter, which seldom seemed to be in contact with the small seeds. The position of the gravel may have improved emergence by providing points of contact for the seed to push against during radicle penetration.

The range of temperatures between microsites on any one day was never greater than $4.2^{\circ} \mathrm{C}$. Differences in seedling emergence in this greenhouse study are probably not related to temperature differences. Under field conditions with much higher incident solar radiation, soil shading by gravel or litter would affect soil temperatures much more than in the greenhouse.

This study showed that under high soil water conditions $>0.03$ MPa matric potential), gravel, litter, and cracks produced significantly more seedlings of sideoats grama, blue panic, and Cochise lovegrass than the bare soil surface. However, results from watering on days 1 and 5 are probably more indicative of Southwest rangeland conditions during the summer rainy season. Under these conditions, the microsites also produced greater seedling emergence than the bare soil surface.

Cochise lovegrass emerged well in gravel microsites under a variety of soil water conditions. It may be practical to broadcast seed small-seeded lovegrasses onto gravelly rangeland soils with little or no seedbed preparation. The ability of small-seeded lovegrass seeds to emerge from undisturbed seedbeds with gravel surfaces may help to explain their success in spreading and dominating coarse-textured soils in southern Arizona (Cable 1971, Cox and Ruyle 1986, Cox et al. 1988).

\section{Literature Cited}

Bleak, A.T., and A.C. Hull. 1958. Seeding pelleted and unpelleted seed on four range types. J. Range Manage. 11:28-33.

Cable, D.R. 1971. Lehmann lovegrass on the Santa Rita Experimental Range, 1937-1968. J. Range Manage. 24:17-21.

Campbell, M.H., and F.G.Swain. 1973a. Factors causing losses during the establishment of surface-sown pastures. J. Range Manage. 26:355-59.

Campbell, M.H., and F.G. Swain. 1973b. Effects of strength, tilth and heterogeneity of the soil surface on radicle-entry of surface-sown seeds. J. Br. Grassl. Soc. 28:41-50.

Collis-George, N., and J.E. Sands. 1959. The control of seed germination by moisture as a soil physical property. Aust. J. Res. 10:628-636.

Cook, C.W. 1958. Sagebrush eradication and broadcast seeding. Utah Agr. Exp. Sta. Bull. 404.

Cox, J.R., H.L. Morton, T.N. Johnson, G.L. Jordan, S.C. Martin, and L.C. Fierro. 1982. Vegetation restoration in the Chihuahuan and Sonoran Deserts of North America. USDA, Agr. Res. Serv., Agr. Reviews and Manuals. ARM-W-28. Oakland, Calif.

Cox, J.R., H.L. Morton, J.T. Lebaume, and K.G. Renard. 1983. Reviving Arizona's rangelands. J. Soil and Water Cons. 38:342-345.

Cox, J.R., and M.H. Martin. 1984. Effects of planting depth and soil texture on the emergence of four lovegrasses. J. Range Manage. 37:204-205. 
Cox, J.R., M.H. Martin-R., F.A. Ibarra-F., and H.L. Morton. 1986. Establishment of range grasses on various seedbeds at creosotebush (Larrea tridentala) sites in Arizona, U.S.A., and Chihuahua, Mexico. J. Range Manage. 39:540-546.

Cox, J.R., and G.B. Ruyle. 1986. Influence of climatic and edaphic factors on the distribution of Eragrostis lehmanniana Nees in Arizona. J. Grassl. Soc. So. Afr. 3:25-29.

Cox, J.R., M.H. Martin-R., F.A. Ibarra-F, J.H. Fourie, N.F.G. Rethman, and D.G. Wilcox. 1988. The influence of climate and soils on the distribution of four African grasses. J. Range Manage. 41:127-139.

Dowling, P.M., R.J. Clements, and J.R. McWilliam. 1971. Establishment and survival of pasture species from seeds sown on the soil surface. Aust. J. Agr. Res. 22:61-74.

Eckert, R.E., Jr., F.F. Peterson, M.S. Meurisse, and J.L. Stephens. 1986. Effects of soil-surface morphology on emergence and survival of seedlings in big sagebrush communities. J. Range Manage. 39:414-420.

Evans, R.A., and J.A. Young. 1970. Plant litter and establishment of alien annual weed species in rangeland communities. Weed Sci. 18:697-703.

Evans, R.A., and J.A. Young. 1972a. Microsites requirements for establishment of annual rangeland weeds. Weed Sci. 20:350-356.

Evans, R.A., and J.A. Young. 1972b. Germination and establishment of Salsola in relation to seedbed environment. II. Seed distribution, germination, and seedling growth of Salsola and microenvironmental monitoring of the seedbed. Agron. J. 64:219-224.

Harper, J.L., J.N. Clatworthy, I.H. McNaughton, and G.R. Sagar. 1961. The evolution and ecology of closely related species living in the same area. Evolution 15:209-227.

Harper, J.L., J.T. Williams, and G.R. Sagar. 1965. The behavior or seeds in soil. I. The heterogeneity of soil surfaces and its role in determining the establishment of plants from seed. J. Ecol. 53:273-286.
Harper, J.L. 1977. Population biology of plants. Academic Press, London. Hillel, D. 1982. Introduction to soil physics. Academic Press, Orlando, Florida.

Humphrey, R.R. 1958. The desert grassland. Bot. Rev. 24:193-252.

Hyder, D.N., A.C. Everson, and R.E. Bement. 1971. Seedling morphology and seeding failures with blue grama. J. Range Manage. 24:287-292.

McWilliam, J.R., R.J. Clements, and P.M. Dowling. 1970. Some factors influencing the germination and early seedling development of pasture plants. Aust. J. Agr. Res. 21:19-32.

Nelson, J.R., A.M. Wilson, and C.J. Goebel. 1970. Factors influencing broadcast seeding in bunchgrass range. J. Range Manage. 23:163-169.

Roundy, B.A., and G.L. Jordan. 1988. Vegetation changes in relation to livestock exclusion and rootplowing in southeastern Arizona. The Southwestern Natur. 33:425-436.

Sheldon, J.C. 1974. The behavior of seeds in soil. III. The influence of seed morphology and the behavior of seedlings on the establishment of plants from surface-lying seeds. J. Ecol. 62:47-66.

Sokal, R.R., and F.J. Rohlf. 1981. Biometry. 2nd edition. W. H. Freeman and Co., New York.

Stoddart, L.A., A.D. Smith, and T.W. Box. 1975. Range management. McGraw-Hill, New York.

Vallentine, J.F. 1989. Range development and improvements. 3rd edition. Academic Press. San Diego.

Winkel, V.K., and B.A. Roundy. 1991. Effects of cattle trampling and mechanical seedbed preparation on grass seedling emergence. J. Range Manage. 44:176-180.

Should we Dial a-Satellite to find your new address? Just sending us your new address along with an old label will probably get your journai to you faster. (No criticism of satellites intended!) Send the information to Society for Range Management, 1839 York Street, Denver, Colorado 80206. 